ISSN: 2162-3104 Print/ ISSN: 2166-3750 Online

Volume 8, Issue 3 (2018), pp. 1398-1407

(C) Journal of International Students

http://jistudents.org/

doi: 10.5281/zenodo. 1254601

\title{
Creating Peace Across Borders: The East-West Path to Unity
}

\author{
Dian Mitrayani \\ University of Wisconsin-Milwaukee, USA \\ Robert "Don" Peel \\ University of Hawai 'i Mānoa, USA
}

\begin{abstract}
This article is based upon autobiographical narratives of two students exploring their experiences in finding commonality through an institutionalized domestic and international student community. Both students' paths intersected at the East-West Center (EWC), an independent, public, nonprofit organization formed by the US Congress in 1960 with the goal of bringing people together through cooperative study, research, and dialogue. The co-authors describe various factors that facilitated cultivating inner peace and minimize imposed oppressive tendencies. In particular, they analyze the importance of a learning environment that motivates each student to deeply reexamine their relationship to cultural and disciplinary boundaries, through exposing them to multifaceted perspectives. Their conclusions highlight the importance of EWC as a place where both domestic and international students can build dialogue, debate, and learn from each other, across disciplinary sectors in a relaxed setting. EWC, with its unique diplomatic-building environment, is a learning prototype that has the potential to unify global diversity through developing unique partnerships of empowerment.
\end{abstract}

Keywords: East-West Center, sustainable peacebuilding, multicultural friendship, collaborative education institution

Educational institutions that attract a diverse range of students from around the world, and offer collaborative learning environments, play an important 
role in unify international communities. These institutions are incubators for creating multicultural strategies to address global issues and conflicts (Kester, 2016; Millican, 2018). Such environments can stimulate crosscultural knowledge exchange through the development of multicultural friendships and help intensify unification processes (Bochner, McLeod, \& Lin, 1977). As an example, the East-West Center (EWC) in Hawai' $i$ is an institution "established by the United States Congress in 1960 as a national educational institution to foster better relations and understanding among the peoples of the United States, Asia, and the Pacific islands through programs of cooperative study, training, and research" (East-West Center, 2017).

The co-authors first met as international students residing in the EWC dormitories, while attending graduate studies at the University of Hawai'i Manoa (UHM). In this article, we share some of our experiences, triggered by the EWC environment, which led to an examination and expansion of our identities. Our intellectual development through the journey steered us both into the field of sustainable peacebuilding, where we continue to collaborate in research and peacebuilding action.

\section{CONVERGING ON THE UNITED STATES FROM NORTH AND SOUTH}

\section{Personal Context of the Co-Authors}

We were raised within different regional contexts and cultures, which shaped our narrations of self, yet our story is dominated by commonalities instead of differences. Baby boomer author, R. Don Peel, is a Caucasian male born and raised in Canada. In 2005, Don decided to retire at the age of 59 after a rewarding but challenging 26-year career as a geologist with the Alberta Provincial Government. Late in his career, Don's geological training was heavily influenced when he participated in an educational outreach program offered to public schools by the Association of Professional Engineers and Geoscientists of Alberta (APEGA). While teaching Grade 3 students about rocks and minerals, his perspective of geology shifted. Young unbiased minds of students posed many questions that challenged some of the scientific assumptions that were taught during his university studies in the 1970s. Ultimately, it was these nine-year-old students who triggered a need for a 54-year-old professional to re-educate himself through obtaining a Master's degree in Earth Sciences (2000-2004). During these graduate studies, as a measure to augment his government work mandate, he explored different avenues to develop policy that would stimulate sustainable mining practices. Given the complexities surrounding the concept of sustainable development, the four years of research offered 
more questions than answers. The outcome further motivated him to continue the research effort by enrolling in the Department of Urban and Regional Planning at the University of Hawai'i at Mānoa (UHM). Coupled with a strong initiative sense and the UHM Strategy Plan with sustainability parameters, Don chose the UHM after extensively researching universities with programs focused on the concept of sustainable development.

Millennial author, Dian Mitrayani, is a female of Chinese ethnicity born and raised in Indonesia. In 2005, she was in her early career as an interior designer in Indonesia. She enjoyed her line of work but felt a strong call to pursue her passion for youth-related work. During this time, she actively volunteered in a faith-based, social-oriented youth organization on weekends. In Indonesia, social-related work, including youth work, receives little support, making them undesirable career options only to be handled on a volunteer basis (Chen, 2009; Santoso, 2016; Shin et al., 2018). The quest to pursue the passion for youth work led her to explore alternative career options, triggering the need to apply for a graduate studies scholarship. She also felt a strong desire to locate a safer learning environment, due to the 1998 political riot where there was prosecution against Chinese Indonesians (Purdey, 2002; Sai, 2006). Successfully being granted an Asian Development Bank (ADB) scholarship, she chose the Urban and Regional Planning Program at UHM. She felt this line of study provided ample career opportunities to work within communities, opening access to young people. The outcome of each of our decisions created a collision of cultures as our paths connected at the East-West Center.

\section{Building Friendship: Meeting in East-West Center}

We both became members of the EWC multicultural community on August 2006 and soon the EWC dormitory environment felt like a new home. However, the option of living in the EWC community comes with the obligations to achieve the EWC's mission of stimulating relationship building. Thus, as community members, we had to be active in many EWC community activities. Our EWC residency and required extracurricular activities proved to be a highly positive experience as it soon became the spawning ground to develop common goals for building an academic action community.

EWC's community activities started with orientation sessions that introduced the international students to the lifestyle of Hawai' $\mathrm{i}$ and the UHM. The uniqueness of Hawaiian culture and history resonated with both of us. The history of Hawai'i, as a state that was built on American colonization, illegal annexation, and the suppression of indigenous language and culture, matched the mounting evidence of historical injustices we had 
become aware of in our respective countries (Goodyear-Ka'opua, Hussey, \& Wright, 2014; Sai, 2011; Vogeler, 2009). Don's initial graduate studies had revealed the oppression of the Canadian indigenous population (Depalma, 1998; Johnson, 2000; Milloy, 1999). Dian was unaware of the oppression of indigenous peoples in North America. However, she also understood how Chinese Indonesians, as an ethnic minority in Indonesia, faced similar oppressive tactics. They were banned from using Chinese language, were forced to change their Chinese names to an Indonesian context, and could not celebrate any Chinese cultural celebrations until 1998. There is also discrimination in terms of access to public education and civil servant jobs (Coppel, 2002; Heryanto, 1998; Lindsey, 2005; Suryadinata, 2004). The orientation gave both of us an awareness of how this lingering oppression still permeates the globe. Tackling oppression is a focus for both authors and gives us a strong shared identity. Our lens of intersectionality taught us where our identity (i.e., gender, race, sexual orientation) is closely intertwined and affects the experience each person has of oppression (Cho, Crenshaw, \& McCall, 2013; Crenshaw, 1989; Freire, 2000; Mattsson, 2014; Rawls, 2005). This understanding inspired us to work together with oppressed communities in Hawai' $i$ as a strategy to challenge our views of our own positionality with respect to oppression.

\section{Understanding and Building "Peace-Self"}

The concept of sustainable peacebuilding focuses on the achievement of peace through addressing the conditions that lead to conflict, such as: poverty, environmental degradation, resource scarcity, and human rights violations (Bajaj \& Chiu, 2009; Ricigliano, 2012; UNESCO, 2012). To us, these issues are beyond solving as individuals. We therefore mutually agreed that the first step towards sustainable peacebuilding action is finding peace within ourselves. Both of us subscribe to developing the "peace-self" as an act of challenging our own internalized idea of oppression. Freire (1998) stated that, "I like to be human because in my unfinishedness I know that I am conditioned. Yet conscious of such conditioning, I know that I can go beyond it, which is the essential difference between conditioned and determined existence" (p. 54). Freirean philosophy served as our method of understanding and being mindful of the conditions of oppression. The understanding of our oppressive conditioning helped us to assess our thought patterns, which had a tendency to hamper developing more productive action plans. Don found that by regularly practicing meditation, the calming effect on his mind seemed to correlate with more satisfying achievements in his life. Dian relied on the meditation aspect of prayer in 
order to induce inner peace, especially when dealing with stressful situations.

The relaxed setting of the EWC campus surrounded by the natural Hawaiian environment also induced a sense of peace. This environment, in combination with the community-building activities, activated numerous dialogue exchanges between us to mutually expand our perceptions and understandings on what we can do to challenge oppression. We concluded it was the "non-peaceful" aspects of our life that steered us towards the development of interest in sustainable peacebuilding, as a tool to challenge oppression. A non-peaceful experience for Dian that peaked her desire for change was the 1998 racial riot in Indonesia. For Don, it was the unsustainable mining practices that continued despite his best efforts to diagnose and recommend corrective measures. Don perceived sustainable peacebuilding through his studies on sustainable development, where the unsustainable practices of his generation should not impact the resources of future generations. For Dian, it meant focusing on the investment of human capital, especially the oppressed groups of people, such as young people or women, as the key component of sustainability and peace development.

Building our peace-selves continued through ongoing dialogues between us as the dorm life offered us the opportunity to join in a collectivist culture. We utilized food as a healing medium. A common dorm kitchen is where we shared our memories of "non-peaceful" experiences with many students of different ethnicities. Casual conversations in the EWC lounges induced reflection in finding our peace-selves. Before focusing on changing behaviors of others, we learned about each other's oppression stories and how we could build our peace-selves from within. Important elements of our dialogue emerged from the juxtaposition of our identity, east vs. west, south vs. north, female vs. male, youth vs. elder, member of national minority vs. member of national majority. These juxtapositions expanded our hope of sustainable peacebuilding, which we shared with different groups of people. Freire (2000) describes our next step for peace-selves in which "true solidarity is found only in the plenitude of this act of love, in its existentiality in its praxis" (p. 50). Our dialogue became our motivation for a praxis in challenging oppression. The dialogue first turned into action through entering the Chaminade University's Peace Program essay contest on the topic of "Creating Peace Across Boundaries." In the essay, we described our unifying and empowering learning that was triggered by our diversity. We won first prize and the success motivated a stronger drive for the deeper development of our peace-selves as we continued through our EWC education experience. 
Another EWC initiative that bonded our intellectual development was the requirement for EWC students to take one of many EWC certificate programs. Don enrolled in the Leadership certificate program to gain benefits associated with leadership development, such as the improvement of influencing techniques to change undesired conditions. Dian took the program with great reluctance as she did not see the connection between this coursework and her future. Also, the reluctance came from the mandatory aspect of the Leadership program. However, this feeling slowly changed after she joined the program for one semester. This course "forced" scholars to meet and work together as a cohort. It also provided a collaborative environment to discuss leadership in different contexts and cultures. Dian felt a sense of freedom in expressing her opinion and stories in the classroom, which was different from her Indonesian rote-learning education experiences. A service learning component of the program challenged both of us to practice the leadership theories that we learned. Service learning introduced us to local in-need communities and also exposed us to types of oppression that local communities experience (i.e., poverty, food desert) while also providing us with an opportunity to act.

\section{Peace Action}

The most important outcome emerging from peace-self development is the continuous quest of action that stimulates peace. We attribute that the action was a direct result of the EWC incubator environment stimulating dialogue and collaboration. As an elder and a youth, the flexibility of the EWC allowed us to communicate across a generation gap and share the different influences that have shaped our lives. We concluded that sustainable peacebuilding is more attainable through diversity. More importantly, the communication between us triggered the notion that the EWC, along with the associated educational institutes in Hawai'i, provide unequalled opportunities to serve as conduits for creating peacebuilding on- and off-campus community settings.

Another example of action occurred through an organizational evaluation project with a Native Hawaiian mentoring group, Ke Ola Hou. As part of an Urban Planning practicum class, we were members of an evaluation team of Ke Ola Hou. The intention of the project was to conduct an organizational evaluation process to empower the Ke Ola Hou staff and students. For this off-campus community project, the EWC became a coworking space that gave us the freedom of our "home," where we could relax, eat, chat, and work at any time, day or night. We could also communicate with other EWC scholars, soliciting their knowledge. This environment was far superior to any other study space options. 
The connection between our academic journey aligned with our desire to use the EWC as a conduit for our work and inspire others into action, both on and beyond the UHM campus. EWC became our center to connect people from diverse backgrounds to Hawaiian communities. We shared our evaluation work in a conference on service learning that the EWC and UHM promoted. At the conference, our involvement went beyond knowledge dissemination by providing a networking place for Ke Ola $\mathrm{Hou}$ high school students with UHM and EWC scholars. Besides giving the high school students a taste of university life, the Ke Ola Hou organization was rewarded with opportunities, including scholarships, all which were empowering actions for the youth.

The diversity of ethnicities, cultures, experiences, and disciplines within the EWC collaborative community offered unlimited opportunities for action, stimulated by any imagination. This experience showed us the importance of an educational institution that empowers students to their full potential, by providing the environment to flesh out and challenge undetected oppressive tendencies (Dewey, 1997; Eisler, 2001; Freire, 2000; Mitra, 2013; Mitrayani \& Peel, 2016; Robinson \& Aronica, 2016; Wagner \& Dintersmith, 2015).

\section{CONCLUSION}

This personal narrative was written to reflect and convey the development of an intercultural friendship and shared identity during our residency in EWC (Baxter, 1987; Gaines \& Brennan, 2001; Wood, 2000). Sustainable peacebuilding became the shared relational identity that we passionately strive to strengthen. The relational identity that we share highly influences our "ways of knowing, being, and acting in relation to each other and the outside world" (Wood, 1982, p. 75). The EWC was our catalyst in developing our relational identity where we put high value on the connection between learning, self reflection, community building, and praxis/action. Our relational identity challenged us to continue to expand and use our knowledge. Through the EWC experience, we have developed a life-long learning friendship in which we continue to collaborate in projects that give opportunities towards sustainable peacebuilding.

An outcome from our EWC residency is the growing consciousness where we cast a critical lens on our day-to-day works by acknowledging our oppressive tendencies in a dominant exploitive culture. Currently, Don continues as an independent researcher in effective educational models that give more agency to the students in co-developing, with their teacher, a curriculum that explores and nurtures their natural talents, while building 
their learning interests. His objective is to ensure that his grandchildren are enrolled in such a learning environment. Dian is finishing her doctoral studies in Education at the University of Wisconsin-Milwaukee, where her research focuses on youth leaders as the main agent for change. We consciously reflect upon our position, power, and also the impact of research and action on the communities with which we are involved. Most significantly, this narrative shows us the potential of institutions supporting their scholars towards the development of peace-self and action. Through academic and day-to-day living activities, we utilized what EWC offered in terms of collectivism and collaboration. EWC, along with its selection of both US and international scholars, builds community where differences become an asset. It is our hope that more educational institutes will build on the EWC model to create more diplomatic educational environments of unification.

\section{REFERENCES}

Bajaj, M., \& Chiu, B. (2009). Education for sustainable development as peace education. Peace \& Change, 34(4), 441-455.

Baxter, L.A. (1987). Symbols of relationship identity in relationship cultures. Journal of Social and Personal Relationships, 4(3), 261-280.

Bochner, S., McLeod, B.M., \& Lin, A. (1977). Friendship patterns of overseas students: A functional model. International Journal of Psychology, 12(4), 277-294.

Chen, D. (2009). Vocational schooling, labor market outcomes, and college entry. Washington, DC. Retrieved from

http://documents.worldbank.org/curated/en/771881468049456978/Vocationalschooling-labor-market-outcomes-and-college-entry

Cho, S., Crenshaw, K.W., \& McCall, L. (2013). Toward a field of intersectionality studies: Theory, applications, and praxis. Signs, 38(4), 785-810.

Coppel, C.A. (2002). Studying ethnic Chinese in Indonesia. Singapore: Singapore Society of Asian Studies.

Crenshaw, K.W. (1989). Demarginalizing the intersection of race and sex: A black feminist critique of antidiscrimination doctrine, feminist theory and antiracist politics. University of Chicago Legal Forum, 1(8), 139-167.

Depalma, A. (1998, January 8). Canada's indigenous tribes receive formal apology. The New York Times. Retrieved from http:/www.nytimes.com/ 1998/01/08/world/canada-s-indigenous-tribes-receive-formal-apology.html

Dewey, J. (1997). Democracy and education: An introduction to the philosophy of education.

East-West Center. (2017). East-West Center origins. Retrieved from https://www.eastwestcenter.org/about-ewc/origins

Eisler, R. (2001). Tomorrow's children: A blueprint for partnership education in the 21st century. Boulder, Colorado: Westview Press.

Freire, P. (1998). Pedagogy of freedom: Ethics, democracy, and civic courage. Translated by P. Clarke. Lanham: Rowman and Littlefield. 
Freire, P. (2000). Pedagogy of the oppressed. Translated by M. Bergman Ramos (thirtieth anniversary edition). New York: Continuum.

Gaines, S.O., \& Brennan, K.A. (2001). Establishing and maintaining satisfaction in multicultural relationships. In J.H. Harvey \& A. Wenzel (Eds.), Close romantic relationships: Maintenance and enhancement (pp. 237-253). Mahwah, NJ: Lawrence Erlbaum Associates.

Goodyear-Ka'opua, N., Hussey, I., \& Wright, E.K. (Eds.) (2014). A nation rising: Hawaiian movements for life, land, and sovereignty. Durham: Duke University Press.

Heryanto, A. (1998). Ethnic identities and erasure: Chinese Indonesians in public culture. In J.S. Kahn (Ed.), Southeast Asian identities: Culture and the politics of representation in Indonesia, Malaysia, Singapore, and Thailand (pp. 95114). New York: St. Martin's Press.

Johnson, W. (2000, July 14). Throwing down the gauntlet. The Globe and Mail. Retrieved from https://www.theglobeandmail.com/opinion/throwing-down-thegauntlet/article768793/

Kester, K. (2016). The case of educational peacebuilding inside the United Nations universities: A review and critique. Journal of Transformative Education, 15(1), 59-78.

Lindsey, T. (2005). Reconstituting the ethnic Chinese in post-Soeharto Indonesia: Law, racial discrimination, and reform. In T. Lindsey \& H. Pausacker (Eds.), Chinese Indonesians: Remembering, distorting, forgetting. Singapore: ISEAS Publications.

Mattsson, T. (2014). Intersectionality as a useful tool: Anti-oppressive social work and critical reflection. Affilia-Journal of Women and Social Work, 29(1), 8-17.

Millican, J. (2018). The social role and responsibility of a university in different social and political contexts. In J. Millican (Ed.), Universities and conflict the role of higher education in peacebuilding and resistance (pp. 13-28). New York: Routledge.

Milloy, J.S. (1999). A national crime: The Canadian government and the residential school system, 1879-1986. Winnipeg: University of Manitoba Press.

Mitra, S. (2013). Beyond the hole in the wall: Discover the power of self-organized learning. Retrieved from https://libraryconnection.overdrive.com/media/ \%7B93324BC2-4CE3-43D5-BE4E-33DDDFA1E0DC\%7D

Mitrayani, D., \& Peel, R.D. (2016). Youth participation and leadership: Moving together towards peace education and sustainable development. In S. Singh \& N.D. Erbe (Eds.), Creating a sustainable vision of nonviolence in schools and society (pp. 200-221). Hershey, PA: IGI Global.

Purdey, J. (2002). Problematizing the place of victims in reformasi Indonesia: A contested truth about the May 1998 violence. Asian Survey, 42(4), 605-622.

Rawls, J. (2005). A theory of justice (Original ed.). Cambridge, MA: Belknap Press.

Ricigliano, R. (2012). Making peace last: A toolbox for sustainable peacebuilding: Boulder, CO: Paradigm Publishers.

Robinson, K., \& Aronica, L. (2016). Creative schools: The grassroots revolution that's transforming education. New York: Penguin Books.

Sai, D.K. (2011). Ua mau ke ea = Sovereignty endures: An overview of the political and legal history of the Hawaiian Islands. 
Sai, S.M. (2006). "Eventing" the May 1998 affair: Problematic representations of violence in contemporary Indonesia. In C.A. Coppel (Ed.), Violent conflicts in Indonesia: Analysis, representation, resolution (pp. 39-57). New York: Routledge.

Santoso, W.M. (2016). Ilmu sosial di Indonesia: Perkembangan dan tantangan. Widjajanti Mulyono Santoso (Ed.). Jakarta: Yayasan Pustaka Obor Indonesia.

Shin, S., Rachmatullah, A., Roshayanti, F., Ha, M., \& Lee, J.-K. (2018). Career motivation of secondary students in STEM: A cross-cultural study between Korea and Indonesia. International Journal for Educational and Vocational Guidance. https://doi.org/10.1007/s10775-017-9355-0

Suryadinata, L. (2004). Chinese and nation-building in Southeast Asia. Singapore: Singapore Society of Asian Studies.

UNESCO. (2012). Shaping the education of tomorrow: 2012 full-length report on the UN decade of education for sustainable development. Retrieved from http://unesdoc.unesco.org/images/0021/002164/216472e.pdf

Vogeler, S. (2009). "For your freedom and ours": The prolonged occupations of Hawai' $i$ and the Baltic States. (Unpublished doctoral dissertation), University of Hawai'i at Manoa, Honolulu.

Wagner, T., \& Dintersmith, T. (2015). Most likely to succeed: Preparing our kids for the innovation era. New York: Scribner.

Wood, J.T. (1982). Communication and relational culture: Bases for the study of human relationships. Communication Quarterly, 30(2), 75-84.

Wood, J.T. (2000). Relational communication: Continuity and change in personal relationships. Belmont, CA: Wadsworth Pub.

DIAN MITRAYANI, M.S.Ed., M.URP., is a Ph.D. candidate in Social Foundations of Education program at the University of Wisconsin-Milwaukee with a focus on youth leadership and civic engagement. Email: mitrayani@gmail.com

R. DON PEEL, PGeo. Hon. FEC. FGC., obtained Exploration Certification (Northern Alberta Institute of Technology, 1969) and a BSc. degree in Geology/Geography (University of Alberta, 1974), which aligned him to a rewarding career as a geoscientist. Having completed the Educational Foundations Program at the University of Hawai $i$ (2009-2014), he plans to pursue a doctoral degree in education focused on youth empowerment for achieving sustainable development. Email: rpeel@hawaii.edu 